\title{
A TRANSLATION EQUIVALENCE ANALYSIS OF ABSTRACT TRANSLATION IN FACULTY OF COMPUTER SCIENCE UNIVERSITY OF BANTEN JAYA 2019 Artica Rizza Anzani ${ }^{1}$, Sisca Wulansari Saputri' ${ }^{2}$, Aa Qona'atun ${ }^{3}$ University of Banten Jaya Serang, Indonesia anzani9295@gmail.com siscawulansari.saputri@gmail.com aagonaatun@unbaia.ac.id
}

\begin{abstract}
The research is content analysis which explores the using of translation equivalences applied in Faculty of Computer Science. Considering that the Faculty of Computer Science indirectly and unconsciously often carry out the process of translation in daily activities in the programming language used. The research thus aims to provide how is translation equivalence and what is the dominant translation equivalence used in translation of abstract internship report in Faculty of Computer Science $7^{\text {th }}$ semester in Banten Jaya University 2019. The data conducted from 3 sections of collecting data which taken randomly from 20 abstract translations of internship report, divided into 10 abstracts from Information System Program and 10 abstracts from Information Engineering Program. The Mona Baker's theories applied in the order to identified and classify the translation equivalences. Furthermore, Miles and Huberman method also used to analyzed the abstract of internship report to find out the first question. In the other hand a formula by Butler used to find out the second question. As the result of this research, the most dominant translation equivalence used is Above Word Level Equivalence with 35 cases $(28.69 \%)$, which followed by Pragmatic Equivalence with 30 cases (24.59\%), Word Level Equivalence with 26 cases $(21.31 \%)$, Grammatical Equivalence with 16 cases $(13.11 \%)$, and Textual Equivalence with 15 cases (12.30\%).The research concludes that the translation equivalence in translations process depend on the translator point of view.
\end{abstract}

Keyword: Translation Equivalence, Abstract, Internship Report, Computer Science 


\section{INTRODUCTION}

Language is one of the method of communication, either spoken or written consisting of the use of words in a structured and conventional way. In this era, English is the one of the important language in the world, it be one of the International language that used in the world. Many medium communication used of English language as the primary. Therefore, the translations process is needed to provide the reader from different culture, language and country to understand about the content of the medium communications.

Newmark (1988) stated that "translation is rendering the meaning of a text into another language, and it is used for multilingual notices, which have at times appeared increasingly conspicuously in public places". In the other hand, Nida and Taber (1982) Stated that translation consist of reproducing the language with the closest natural equivalence with the target language without removing the meaning and style from the source language. Its mean translations process not only process of changing the word, but also in the translation process it should be considering the cross cultural, meaning, and habitual between two different languages.

The translation is one of the subject which learnt by English education program at Banten Jaya University depend on syllabus that used in Banten Jaya University. The student of English Education Program at Banten Jaya University familiar with the subject, even the process, theory, procedure or the equivalence. On the other hand, other programs do not 
learn about translations, while the translation process is needed to transfer the abstract of internship report in Banten Jaya University, one of them is Faculty of Computer Science (FILKOM).

The faculty of computer science (FILKOM) is one of the faculty in Banten Jaya University which undirectly familiar with the translation process on their daily. Considering that the Faculty of Computer Science indirectly and unconsciously often carry out the process of translation in daily activities in the programming language used. In the other hands, internship is a experiential education form between knowledge and theory in the classroom. The internship gives students the opportunity to gain valuable applied experience and make connections in professional fields they are considering for career paths. The internship in Faculty of Computer Science Banten Jaya University starts in March until the end of the academic year for one month. Then the students of Faculty of Computer Science Banten Jaya University should submit the internship report as they finish the internship. The arrangement structure of internship reports in Banten Jaya University is different for every faculty, but it still has some similarity on several items. One of them is abstract. The internship report of Banten Jaya University must be the abstract in two different language, Indonesia and English. The arrangement of the structures has similarity with the research paper. Therefore, the abstract should be written as good as possible because it represents the whole content of the internship report. On the other hand, 
the process of translating the abstract into the other language is needed for the translation process by the author of the internship report.

\section{a. Definition of translation}

Translation is an activity of transferring meaning even from one language into another language. Newmark (1988) stated that translation is a process of transferring meaning of the text into the another language to provide the information into various language, this process is transferring the linguistics or cultural meaning into another language with consider the equivalences from the target language. Nida and Taber (1982) state that translating consists of the process of analyzing or transferring language from the source language into the target language, and the last is restructuring the text from source language into target language by using the closest meaning both of target language and source language. In that expert definition, it can conclude that translation is the process of transferring text from source language into target language by considering the meaning and the culture using the closest natural equivalent meaning and also considering the style used by the original author.

\section{b. Translation Process.}

The process of translation can be defined as the activity of how is translator translate the source language. The translations process is often used by a translator as a guidance in translating a text from the source language into target language. Newmark (1988) states that the translation process begins with choosing the method of 
approach in translating. He stated that the translation levels divided into 4 levels, that are SL text Level, the referential level, the cohesive level, and the level of naturalness. In the other hands, Nida stated that three stages of translation process, that are Analysis, Transfer, Structuring.

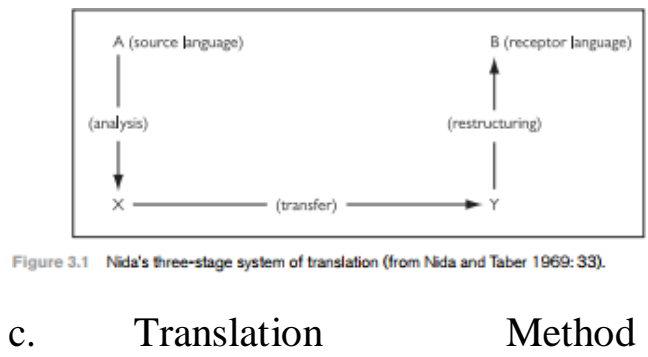

Newmark in Baihaqi

(2017:33) said that there are two translation methods: source language emphasizes method and target language emphasizes method. Newmark explains that SL emphasizes method that the translation results are from express from the source language, but TL emphasizes method are different from SL emphasize method.TL emphasizes method that the translation results are from how to express the text by target language.
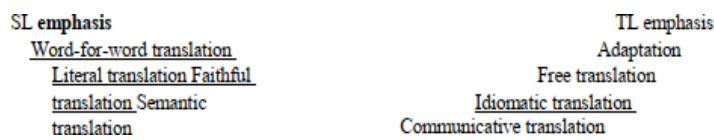

d. Translation Procedure

Vinay and Darbelnet explained that translators can choose from two method of translating, that are direct and oblique translation. In some case of translation, the translator can transpose the source language into target language element by element.

e. Translation Equivalence

According Vinay and Darbelnet in Munday (2010 "equivalence refers to how the language can describe into the target language in the same situation by 
different style or structural meaning. In the other hands Mona Baker on her book In Other Hands (2006) said that translation equivalence are divided into 4 as presented below:

\section{Word Level Equivalence}

When the translator found the text from the source language the first thing that should be seen is the word, the translator should be find out the same meaning in target language without changing the meaning. Sometimes, the target language is not have the similarity of the language, in the other hands the translator should be transfer the meaning without changing the information and the meaning. Furthermore, the translators should be find out the equivalences in the target language by using the descriptions about the source language word. The word level equivalence is a translation process which analyzes morphemes and words.

2. Above Word Level Equivalence.

The word level and above word level has similar definition, according Baker (2011) the above level equivalence is relationship between words that produce an idiom or collocation. The collocation is the relationship between 2 words or more. On the other hand the idiom is the relationship between two words or more which have the derivative meaning.

\section{Grammatical Equivalence}

Grammar is organized along two main dimensions: morphology and syntax. Morphology covers the structure of word, the way in which the form of a word changes to 
indicate specific contrasts in the grammatical system. In other hands syntax covers the grammatical structures of groups, clauses, and sentences. ting information specified in the source text.

\section{Textual Equivalence}

$$
\text { Emzir (2015) said }
$$

"kesepadanan tekstual mengacu pada kesepadanan antara teks BS dan teks BT dalam istilah nformasi dan kohesi". On the other hand, Baker in Baihaqi (2017) state that textual equivalence occurs in cohesion orders. Cohesion is part of the external structure, and connects one sentence to another sentence in a text.

\section{Pragmatic Equivalence}

Pragmatics is the study of language in use. It is the study of meaning, not as generated by the linguistics system but as conveyed and manipulated by participants in communicative situations. In doing this will be venturing beyond the textual level of connecting sentences and paragraphs together and identifying various fitures.

\section{f. Definition of Abstract.}

According Webster's Desk Dictionary of the English Language, it is said that "Abstract is a summary of a statement, etc". Base on the definition above it can be assumed that abstract especially related to the result of research, and other scientific article of writing for a journal is a kind of short or very brief of condensed text of final report that represents all activities that the writer or researcher has done which is limited between 250 up to 500 words or written within two pages at a the most or less. 


\section{METHOD}

This research is intended to know how is translation equivalence of abstract internship report and what is the dominant translation equivalence used in translation of abstract internship report in faculty of Computer Science 7th semester Banten Jaya University 2019.

In inferencing and analyzing the translation equivalence used in the abstract of internship report of Computer Science Faculty Banten Jaya University 2019, it follows the fundamental rules for qualitative content analysis. The method is using of Miles and Huberman analysis by using Mona Baker theory in her book "In the Other Words: a coursebook on translation". The data conducted from 3 sections of collecting data which taken randomly from 20 abstract translations of internship report, divided into 10 abstracts from Information System Program and 10 abstracts from Information Engineering Program.

\section{RESULT AND DISCUSSION}

The result of translation procedures analysis can be observed of the following explanations.

The first finding shows the use of translation equivalence Word Level Equivalence. That is a translation process which analyzes morphemes and words. In this case, the author of the internship report abstract translated penulis into the "author" and not using the writer, in the abstract or the research we will be familiar with "author, researcher, or writer" for translated penulis. In the other example, the author translated "Data Flow Diagram 
(DFD)" into the same word "Data

Flow Diagram (DGD)", the author kept the original language of abbreviation from Indonesian language as the Source language into English.

The second finding is Above Word Level Equivalence. The word level and above word level equivalence has similar definition, the differences is above word level equivalence is a relationship between words that produce an idiom or collocation. In the other hands, the collocation is relationship between two words or more which have derivative meaning, the difficulties encountered by translators as a result of difference in the lexical patterning of the source and target language. In this research find that the author translated "Wireless Local Area Network (WLAN)" into the same meaning in target language, the Wireless Local Area Network (WLAN) as we know is one of the many absorption languages from English language by using translation procedure borrowing, in this research also found that the author translate Komite Olahraga Nasional Indonesia (KONI) Provinsi Banten into "Indonesian National Sports Committee (KONI) of Banten Province", the author used and explain the meaning by using the target language word by word without deleting the meaning from the source language even not using the same word from the source language .

The third is Grammatical Equivalence, the grammatical itself is organized along two main dimensions: morphology and syntax. Morphology covers the structure of 
words, the way in which the form of

a word changes to indicate specific contrasts in the grammatical system.

In other hands syntax covers the grammatical structures of groups, clauses, and sentences. The most important difference between grammatical and lexical choices, as far as translations is concerned, is that grammatical choices are largely obligatory while lexical choices are largely optional. Differences in the grammatical structures of the source and target languages often result in some change in the information content of the message during the process of translations. The change in the information content of the message may be in the form of omitting information specified in the source text. In this case, the author translated 2 modul into "2 modules" as the target language, the translator considering the quantity of the module from source language into target language and told the reader that the modules are not only one (plural). In the other case, the author of internship report of abstract translated dibuat as source language into "created" as a target language that using grammatical equivalence, the translator is considering the tenses of simple past tense in English to translate and indicate the time in the source language.

The fourth is Textual equivalence, the textual equivalence occurs in cohesion order which connecting one sentence to another sentence in a text. The interactional organization of the sentences is to suggest that clause divided into two segment, that is theme and rheme. In this research find out that The author translated the text by using textual 
equivalence by considering the coherence of the text by using "however" to translate namum and explain the weakness of the system which is used in PT EDS Manufacturing Indonesia. The writer told the reader that the system of PT EDS Manufacturing Indonesia still has problems when running this webbased application system, for example, the system and the menu on the program have not neatly structured and are not working properly. In other case, the author used textual equivalence to translate the text from source language into target language. The author is considering coherence of textual by using "thus" for connecting the hope expectation and result that the employees of PT Nikomas Gemilang will be better after using the better system
The last is Pragmatic Equivalence, as we know that Pragmatics is the study of language in use. It is the study of meaning, not as generated by the linguistics system but as conveyed and manipulated by participants in communicative situations. In this research the author used pragmatic equivalence to translate mempercepat waktu from Bahasa Indonesia as source language into "speed up the time" from English as target language. The definition of mempercepat waktu from Bahasa Indonesia is not mean to make the time speed up, but to make the process of the system faster so the user not wasting the time when using the system. In the other case, the author translate mengadakan into "hold" by using pragmatic equivalence, the author told the 
reader that to hold in target language means not holding something but to arrange some questions of interview for several of leadership and employees.

The result above can be summarized as following table of cumulative frequency and percentage of translation equivalence.

After analyzing 20 abstracts taken randomly from the faculty of computer science that are 10 data from the Informatics Engineering study program and 10 data from the informatics system study program, with of a total of 122 cases and analyzed the translation equivalence base on Mona Baker theory by using Miles and Huberman method and used the educational statistic by Butler in Reza (2017) to count the percentage of each equivalence, it can found the results as the following data:

Table of Translation equivalences

\begin{tabular}{|l|c|c|}
\hline \multicolumn{1}{|c|}{$\begin{array}{c}\text { Translation } \\
\text { Equivalences }\end{array}$} & $\begin{array}{c}\text { Total } \\
\text { Data }\end{array}$ & $\begin{array}{c}\text { Percent } \\
\text {-age }\end{array}$ \\
\hline $\begin{array}{l}\text { Above Word Level } \\
\text { Equivalence }\end{array}$ & 35 & $28.69 \%$ \\
\hline $\begin{array}{l}\text { Word Level } \\
\text { Equivalence }\end{array}$ & 26 & $21.31 \%$ \\
\hline $\begin{array}{l}\text { Grammatical } \\
\text { Equivalence }\end{array}$ & 16 & $13.11 \%$ \\
\hline $\begin{array}{l}\text { Textual } \\
\text { Equivalence }\end{array}$ & 15 & $12.30 \%$ \\
\hline $\begin{array}{l}\text { Pragmatic } \\
\text { Equivalence }\end{array}$ & 30 & $24.59 \%$ \\
\hline
\end{tabular}

From the data above it can be seen that the most dominant translation equivalence used by translators is Above Word Level Equivaalence. Above word level equivalence is how the translator express and translate the word that not have the same meaning. Many factors affect translators in translating, one of which is the cultural element that differs between the source language and the target language which makes the translator considered in the 
translation process that results in equivalence in translation. In this case 35 data were found that were 28.69\% which resulted in Above Word Level Equivalence in their equivalence. It means 35 sentences from the total 122 sentences in the 20 abstract data used by the authors of the internship report abstracts at the Faculty of Computer Science are Above word level equivalence. The Second is Pragmatic Equivalence with 30 cases or $24.59 \%$ from 122 sentences, the third is Word Level Equivalence with 26 cases or $21.31 \%$ from 122 sentences, the fourth is Grammatical Equivalence with 16 cases or $13.11 \%$, and the last one is Textual Equivalence with 15 cases or $12.30 \%$ found from 122 sentences.

\section{CONCLUSIONS}

Based on the discussion, it can be resolved that the 20 abstracts of internship report Computer Science Faculty Banten Jaya University 2019 has variant equivalences in every abstract, so not only one translations equivalence found in every abstract translation of internship report. Every writer the abstract translation of internship report has different point of view in translated the abstract from Bahasa Indonesia as the source language into English as a target language. The differences of cultures, situations, process and method of translations made the different result of translated the abstracts. From the analyzed, there are five translation equivalences applied in abstract translation of internship report Computer Science Faculty Banten Jaya University 2019 by Mona Baker with commonly apply the Above Word Level Equivalence for the translation 
equivalence in translated abstract of internship report in Faculty of Computer Science Banten Jaya University 2019. It proves that the translation equivalences used can't be prediction and not have the standard rules, because the differences of theory, process, method, and procedure in process of translating a text will give the different result depend on the translator's point of view.

\section{REFERENCES}

Baihaqi, Akhmad. Penerjemahan dan Kesepadanan dalam Penerjemahan.

Staisman Press. Pandeglang. 2017

Baker, Mona. In Other Words: a Course Book of Translation, Routledge. Taylor \& Francis. Oxon. 2011.

Cresswell, John W. Educational Research: Planning, Conducting and Evaluating Quantitative and Qualitative Research Fourth Edition. Pearson. Boston. 2012.

\section{Emzir. Teori dan Pengajaran Penerjemahan. Rajawali pers.Jakarta. 2015.}

Hatim, Basil. Ian Manson. The Translation as Communicator. Routledge. Taylor \& Francis. London. 1997.

Miles, Matthew B. A Michael Huberman, Johnny Saldana. Qualitative Data Analysisis: A Methods Sources book. Sage Publications. London.

Kumar, Rajit. Research Methodology: a Step-bystep Guide for Beginners. Sage Publications. London. 2011.

Mundai, Jeremy. Introducing translation Studies: Theories and Applications 2nd Edition. Routledge. Taylor \& Francis e-library. London. 2010

Newmark, Peter. A Textbook of Translation. Prentice Hall. British Library Cataloging in Publication Data. Great Britain, 1988.

Nida, Eugine. Charles Taber. The Theory and Practice of translation. E.J Brill, Leiden. Netherlands. 1982.

Reza, Muhammad. An Analysis of Translation Procedures in Translated Thesis Abstracts of Student of Faculty Social and Political Sciences. 2018. 
Sugiono, Metode Penelitian Kuantitatif, Kualitatif, dan R\&D. Alfabeta Bandung.

Bandung. 2017.

Sukimiyadi. A Study on the Quality Abstract Translation of Dissertaion from Indonesia into English. 2014.

Venuti, Lawrence. The Translation studies Reader. Routledge. Taylor \& Francis 2Library. London. 2004. 